\title{
Social Climates in Community Groups: Toward a Taxonomy
}

\author{
Peter E. Politser, M.D.* \\ E. Mansell Pattison, M.D.
}

\begin{abstract}
While communty groups have often helped people cope with stress, little empirical research has been available to guide their use in prevention or treatment. To partly fill this gap, an empirical taxonomy of community groups was derived from ratings of 41 randomly selected groups on 35 dimenstons of Group Structure, Function, and Membership Characteristics. Cluster analysis defined five types. By comparison with other associations, Self-Interest (e.g., liberation and minority) groups rated lower in regulations and had members who were newer to the community. Self-Help groups were highly regulated settings providng support, integration, and developmental aids. Their members had few social relations apart from the family. Social Communion groups rated high on the provision of support for members often lwing without family. Civic Development groups rated highest on dimenstons emphasizing personal development for persons with external sources of support and status. Finally, Recreation groups were casual and briefly attended groups. Their mewbers were younger and less often married than those in other associations. Strategies for group referrals may be implied.
\end{abstract}

During recent years, we have seen a great proliferation of community organizations labelled as Self-Help Groups. Such groups have arisen to help people cope with a myriad of addictions, physical illnesses, developmental crises, and social deprivations. This has been called a "revolutionary" movement, and some of its zealous adherents have predicted that such groups will provide new, more effective forms of treatment.

The role of community associations in promoting human adaptation is neither unique to modern times nor to self-help groups, however. Throughout history, from ancient Greek times to the present, a variety of community associations have served to buffer life stress. Social changes like the decline of communalism in Athens and the advent of the Industrial Revolution were met by a proliferation of social organizations (Anderson, 1971). Widespread disease, such as the black death which devastated European society, resulted in the growth of support groups (Caplan, 1974). The strains of migration for the 19th century immigrants to America fostered organizations like the Sons of Italy to provide companionship and education. Similar groups arose in West Africa among primitives who left their tribes to reside in modern cities (Kerri, 1972; Little, 1972). Even today a variety of social, civic, and other

*Dr. Polister is Clinical Assistant Professor, Dept. of Psychiatry, Unwersity of Michigan. Dr. Pattison is Professor and Chairman of the Dept. of Psychiatry at the Medical College of Georgia, Athens, GA.

This investigation was supported in part by Individual Postdoctoral National Research Service Award \#IF32MH07185 to Dr. Politser from the Mental Health Unit, National Institutes of Health. We wish to thank Richard H Price, Ellot Noma and the revuewers of this Journal for their useful and detalled suggestions. Also, we thank Joan Spirnak, Gregory Watts and Doreen Rott for their assistance. Reprint requests to Dr. Politser. Untversity Hospital-Riverview Building, 900 Wall Street, Ann Arbor. Michigan 48109 . 
groups perform important mental health functions even though they have no roots in the Self-Help Movement. To ease the transitions of adult development, organizations like the Jaycee's teach leadership skills. Likewise, many social groups for the aged supplement declining sources of support.

The clinical relevance of such groups is becoming more apparent. First, there is suggestive evidence that seems to link the adequacy of one's natural social supports to one's physical and mental health (Blau, 1973; Cobb, 1976; Lowenthal \& Haven, 1968; Politser, in press). There is even more specific evidence that suggests a relationship between community group membership and mental health. Members of voluntary groups, for example, are more optimistic, happier, less prone to anomie, and have fewer psychosomatic symptoms (Reddy \& Smith, 1973). Sick families, on the other hand, have fewer voluntary association memberships (Kammeyer \& Botton, 1968). While the causal directionality of these general relationships is unfortunately still unclear, there is also more direct evidence for the impact of some groups upon clinically important outcomes. Membership has, for example, been linked with reduced recidivism for ex-prisoners (Volkman \& Cressly, 1963), weight loss for the obese (Stunkard, 1972), and declining neurotic distress for religious cult members (Galanter, 1977).

Even though some groups appear to help some people, however, membership may have few benefits for others. Groups such as Alcoholics Anonymous have high dropout rates and remaining members have characteristic personality traits. Successful affiliates tend to be more responsible and guilt prone (Trice \& Roman, 1969). Many of those who drop out, conversely, seem to complain about the rigidity of the organization. A plausible interpretation of these differential effects is that they may be determined in large part by the interaction between the characteristics of members and those of the groups themselves. This appears to be true in other settings. In therapy groups, for example, internally oriented persons seem to respond better than externals in nondirective groups (Abramowitz et. al., 1974). In inpatient therapeutic milieux, much of the variance in patient behavior and treatment outcome is not explained adequately by patient or treatment program characteristics alone but by the interaction of the two (Paul, 1969). Likewise, the fit between a person and his environment, in schools, communities, and other settings, appears to have an important relation to a number of mental and physical health attributes (Eddy, 1973; French \& Caplan, 1970; Friedman, 1956; Pervin, 1968; Wechsler \& Pugh, 1967). For community groups that have some clinical value, then, what types of groups may produce the best outcomes for what types of people becomes a critical issue.

An initial step toward filling the need for research in this area, and the intent of this study, is to differentiate between the social climates provided by different community groups and to begin to develop a taxonomy based on these differences. As Lieberman (1975) has noted, the taxonomic approach may facilitate research on the differential effectiveness of groups. Moreover, identifying the characteristics of various community group types may also 
provide valuable information that might ordinarily be overlooked when these groups are utilized by mental health professionals.

Some recent attempts have been made to develop taxonomies of more restricted classes of groups. Singer et al. (1975) attempted to classify training and therapy groups partly on the basis of organizational characteristics and suggested that different individuals might have different "organizational needs." Levy (in press) developed a taxonomy of self-help groups based largely upon their therapeutic elements. These intuitively devised classification schemes provide useful insights. However, especially with highly publicized groups subject to great distortion, an empirically derived taxonomy could be instructive not only in categorizing them but in more accurately distinguishing their characteristics. The object of our study was to provide such a classification and description.

Of course, no simple rule for the development of such a taxonomy exists. The method we have chosen is to develop a set of measures by which groups may be described and then to base one's classification scheme upon the similarity of their measured characteristics (Fredrickson, 1972). Typologies of college environments (Pace, 1968; Pace \& Stern, 1958) and of treatment settings (Moos, 1974; Price \& Moos, 1975) have with some success been developed using this approach.

\section{METHOD}

\section{Subjects}

Forty-one community groups with 1,243 members were randomly selected from a list of 248 associations prepared by the Chambers of Commerce of ten cities in Orange County, California. Prior to selection, we excluded from the list groups that were not voluntary, that had fewer than ten or more than a hundred members, that were organized mainly for profit, or that did not have at least monthly face-to-face meetings. Four trained observers evaluated the groups on the basis of interviews with members, direct observation of at least one typical meeting, and a formal questionnaire distributed to each individual. Eighty percent of members returned their questionnaires. Nine of the 41 groups observed declined to fill out questionnaires altogether Data from these groups was therefore used in the construction of the scale of group structure and function but these groups had to be excluded from the final analysis, which attempted to categorize associations on the basis of structure, function, and member characteristics.

\section{THE COMMUNITY GROUP SCALE}

The basis of these evaluations was the Community Group Scale, composed of three parts and summarized in Table 1. The first of these, the Group Structure Scale, was designed to measure the social climate of the group on the basis of organizational characteristics which could be directly observed or determined from an interview with members. From a review of the literature, ten a priori subscales were formed from logically related items (see Table 1A). A single measure of group size (average attendance) was also included. The subscales were found to be largely independent and to have adequate psychometric properties on the basis of their internal consistencies and intercorrelations (see Table 2). Two subscales which showed low internal 
TABLE 1

\section{Summary of the Community Group Scale}

A. Group Structure Scaie

\begin{tabular}{|c|c|c|c|c|c|c|}
\hline \multirow[b]{2}{*}{$\begin{array}{l}\text { Assigned } \\
\text { Factor }\end{array}$} & \multirow[b]{2}{*}{ Subscale } & \multicolumn{3}{|c|}{ Factor Loadings } & \multirow[b]{2}{*}{ Items * } & \multirow[b]{2}{*}{$\begin{array}{c}\text { Item } \\
\text { We1ght }\end{array}$} \\
\hline & & $\begin{array}{c}\text { Regula- } \\
\text { tions }\end{array}$ & $\begin{array}{l}\text { Role } \\
\text { Demands }\end{array}$ & $\begin{array}{c}\text { Boundary } \\
\text { Control }\end{array}$ & & \\
\hline \multirow[t]{5}{*}{ Regulations } & $\begin{array}{l}\text { Obligatoriness measures } \\
\text { the extent to which } \\
\text { participation in the } \\
\text { group is required }\end{array}$ & 73 & 28 & .10 & $\begin{array}{l}\text { 1. Attendance is sufficiently } \\
\text { critical that non-attending } \\
\text { members are called by phone } \\
\text { 2. Non-participation is punished } \\
\text { by censure or expuision. }\end{array}$ & 6 \\
\hline & $\begin{array}{l}\text { Behavior Control (also } \\
\text { listed under Boundary } \\
\text { Control) measures the } \\
\text { development of norms in } \\
\text { the group. }\end{array}$ & .53 & -36 & .53 & $\begin{array}{l}\text { 1. Specific instructions help } \\
\text { guide member behavior (e.g, } \\
\text { AA's Twelve Steps. } \\
\text { 2. The group openly discusses } \\
\text { specific member behaviors } \\
\text { (e g., overeaters are chas- } \\
\text { tized for ganing weight) } \\
\text { 3 Control is internal with } \\
\text { little extemal influence } \\
\text { (e.g, membership in a na- } \\
\text { tional organdzation) }\end{array}$ & 3 \\
\hline & $\begin{array}{l}\text { Predictability reflects } \\
\text { consistency in various } \\
\text { features of the } \\
\text { meetings }\end{array}$ & 52 & -34 & -.34 & $\begin{array}{l}\text { 1. Percentage of meeting time } \\
\text { consisting of a frirmal } \\
\text { agenda } \\
\text { Percent of all meetings } \\
\text { attended in the last year by } \\
\text { the most regular members } \\
3 \text { Percent of meetings held at } \\
\text { a fixed location }\end{array}$ & 4 \\
\hline & $\begin{array}{l}\text { Definitiveness measures } \\
\text { how kelI defined group } \\
\text { goals and expectations } \\
\text { are. }\end{array}$ & 51 & -.09 & 06 & $\begin{array}{l}\text { 1. Specific group goals are } \\
\text { defined in a written document } \\
\text { or constitution } \\
\text { 2. Formal report }- \text { giling or } \\
\text { ceremonies creat clear roles }\end{array}$ & 4 \\
\hline & $\begin{array}{l}\text { Cont inuity measures } \\
\text { the group's stability } \\
\text { over time }\end{array}$ & .39 & 28 & 18 & $\begin{array}{l}\text { 1. Length of the group's } \\
\text { existence } \\
\text { 2. Frequency of regularly held } \\
\text { meetings } \\
3 \text { Regularity of meetings } \\
4 \text { Fixity of meeting length }\end{array}$ & $\begin{array}{l}3 \\
3 \\
2 \\
2\end{array}$ \\
\hline \multirow[t]{2}{*}{$\begin{array}{l}\text { Role } \\
\text { Demands }\end{array}$} & $\begin{array}{l}\text { Role Complexity mea- } \\
\text { sures the degree of } \\
\text { complexity in inter- } \\
\text { actional transactions }\end{array}$ & .10 & 30 & .08 & $\begin{array}{l}\text { 1. The major type of interaction } \\
\text { between members involves } \\
\text { vigorous mutual interchange. } \\
\text { 2. Type of interaction requires } \\
\text { personal involvement (e.g., } \\
\text { discussing personal opinions). } \\
\text { 3. Individual roles are non- } \\
\text { interchangeable (e g, giving } \\
\text { formal reports). }\end{array}$ & 6 \\
\hline & $\begin{array}{l}\text { Selectivity measures } \\
\text { the extent of role } \\
\text { requirements for en- } \\
\text { trance into the } \\
\text { group }\end{array}$ & -.28 & .72 & .14 & $\begin{array}{l}\text { Stringent requirements must } \\
\text { be met before entrance. } \\
\text { 2. Nembers may be excluded by } \\
\text { vote after a probationary } \\
\text { period }\end{array}$ & $\begin{array}{l}4 \\
6\end{array}$ \\
\hline \multirow[t]{2}{*}{$\begin{array}{l}\text { Boundary } \\
\text { Control }\end{array}$} & $\begin{array}{l}\text { Interaction measures } \\
\text { the extent of coopera- } \\
\text { tion and exchange with } \\
\text { extermal soclety. }\end{array}$ & 40 & -.14 & -.62 & $\begin{array}{l}\text { 1. The group as a whole inter- } \\
\text { acts with a wide variety of } \\
\text { outside groups and agencies } \\
\text { (e g, through community } \\
\text { service projects). } \\
\text { 2. Frequency of interaction. } \\
\text { 3. The character of these in- } \\
\text { teractions is cooperative } \\
\text { rather than competitive }\end{array}$ & $\begin{array}{l}4 \\
2\end{array}$ \\
\hline & $\begin{array}{l}\frac{\text { Behavior }}{\text { measures }} \text { Control } \\
\text { ment of norms in the } \\
\text { group (also Insted } \\
\text { with Regulations) }\end{array}$ & -- & - - & See $11 \mathrm{st}$ & under Regulations - & \\
\hline
\end{tabular}

* Mutiple anchors were used for each Item $1 \mathrm{n}$ the group structure scale and only the highest 15 listed here Copies of the entire scale are available upon request from the author. 


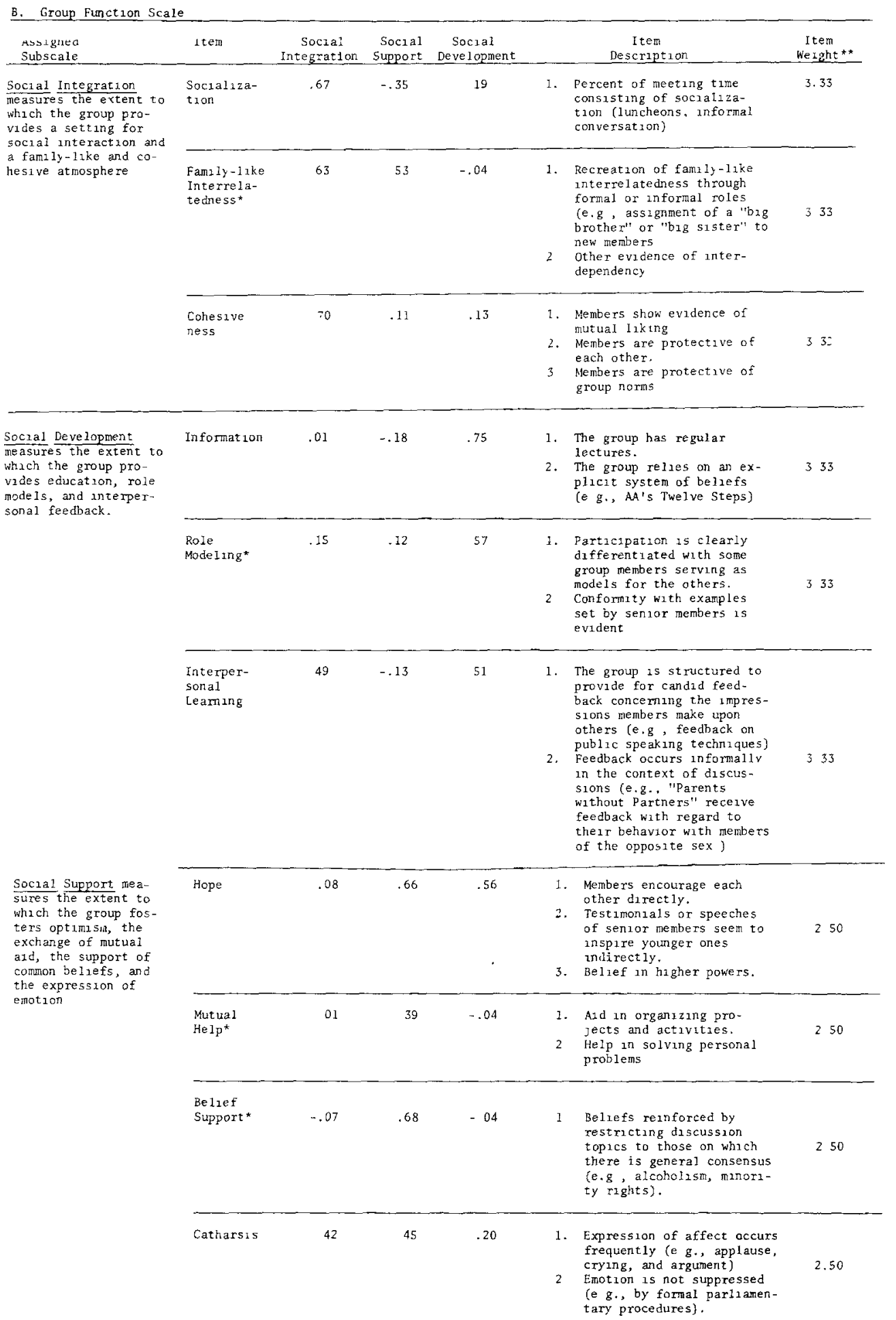

\footnotetext{
* In Yalom's scheme, these itens are labelled respectively, Corrective Recapitulation of the Primary Fam1ly Group, Altruism, Universality, and Imitative Behavior.

* Separate ratings were not recorded for the sometimes multiple components of each ztem, but instructions were to welght the se equally.
} 


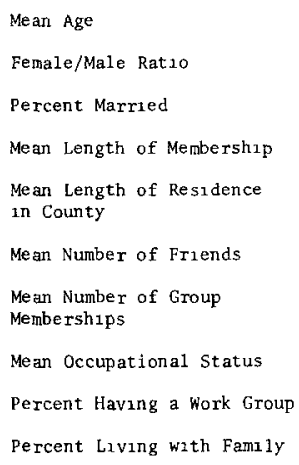

consistency were deleted. In addition, several items which showed low correlations with their subscales were also not included in the final analysis. A second scale, called the Group Function Scale, was a global rating scale concerned with the development of group traits thought to have a therapeutic function. The items scored from observations of group meetings were derived from variables proposed by Yalom (1970) as curative elements in group therapy, based on therapist opinion, patient opinion, and outcome research (see Table 1B). A factor analysis of the items indicated that they could be divided into three largely orthogonal subscales, called Social Integration, Social Support, and Social Development. These subscales also had adequate psychometric properties (see Table 2). The third part, the Group Membership Scale, consisted of questions to identify demographic characteristics of the members (see Table 1C).

The group assessments described related significantly to different indices of satisfaction with the group and were useful in empirically differentiating between them. Roughly eighty percent of the Group Structure and Group Function subscales correlated significantly with multiple indices of member satisfaction in a ten-item questionnaire. Also, after an a priori categorization of groups into four types in early stages of the project, group type had a significant $(p<.05)$ effect on roughly sixty percent of the subscales using a one-way analysis of variance. All of the subscales demonstrated at least moderate interrater reliability $(\hat{\mathbf{r}})$ (see Table 2 ).

\section{METHOD OF ANALYSIS}

After each group was evaluated, factor analysis was used to provide a compact interpretable way of summarizing the data from the Group Structure Scale and to form subscales from the group function items. Explanation of results was facilitated by categorizing each subscale according to the factor on which it had its heaviest loading (see Table 1). Since factor 
analysis of the two scales together yielded substantially the same factors as their separate analysis and since the separate analysis was somewhat more easily interpreted, only the latter results are reported.

Next, a correlation of each of the groups with each of the others across all subscales was used to form a measure of similarity between groups, and the similarity matrix provided the basis for a cluster analysis. This enabled us to define homogeneous classes of groups and to derive a taxonomy based upon their measured characteristics.

\section{RESULTS}

From factor analysis of the ratings on each group structure subscale, three factors, conceptualized as Regulations, Role Demands, and Boundary Control were identified (see Table 1A). The Regulation factor had heaviest weightings on aspects of clarity and control in the group (Predictability, Definitiveness, Behavior Control, Obligatoriness, Interaction, and Continuity). Role Demands were most directly related to role requirements for

TABLF 2

SUBSCALE INTERYAL CONSISTENCIES' ${ }^{-}$, INTERTORRELATIONS"

AND INTFR-RATER RELIABILITIES

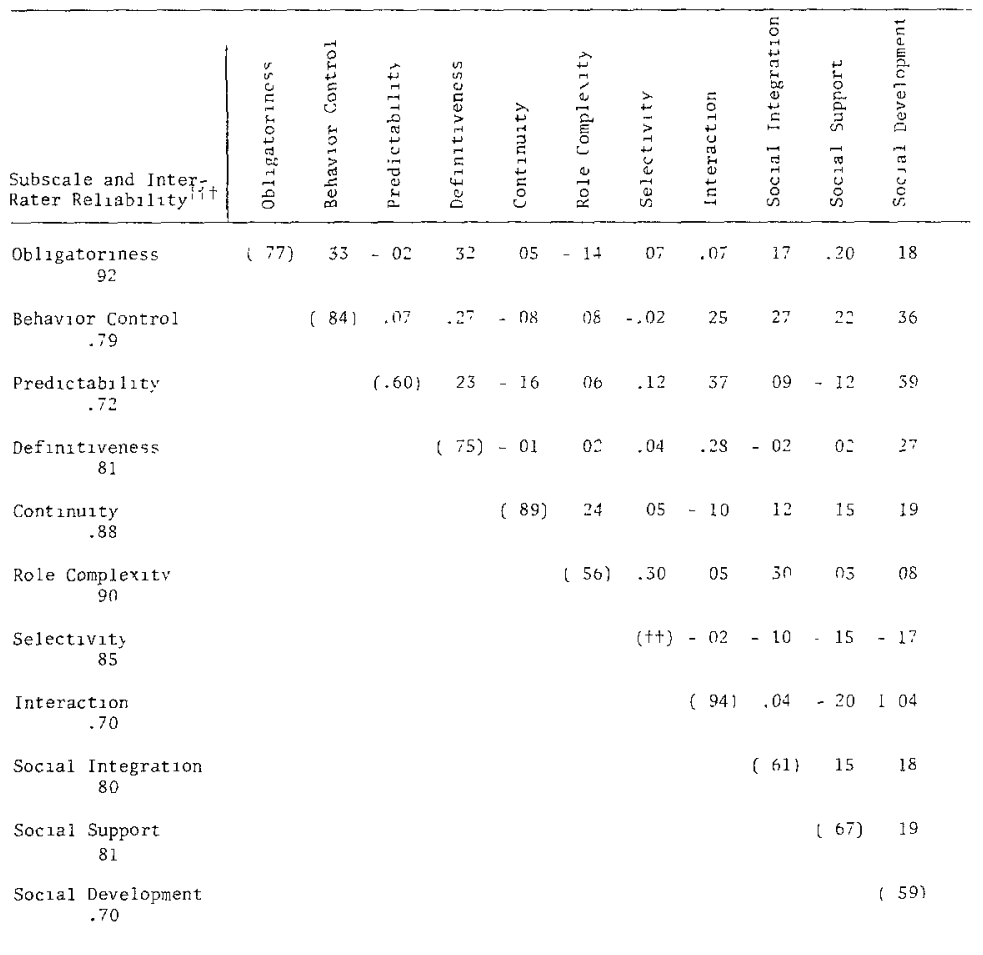

t Internal consistencies are in parentheses along diagonals (Cronbach's a) and Intercorrelations are off diagonal.

Hitems were not scored separately on this subscale, making it imnossible to compute internal

consistency. Inter-rater reliability, however, was adequate ('́r 85)

TIntraclass correlation. 
entrance (labelled Selectivity) and also to Role Complexity. They had a negative relation to Behavior Control and Predictability. Finally, the Boundary Control of the group seemed most clearly to indicate lack of interaction of the group with the outside community although aspects of the development of internal norms (Behavior Control) seemed also to be associated. Because the loading of Behavior Control on this factor was nearly as high as its loading on Regulations, it is listed on both in the Table Summary (1A).

Three factors were found to describe the ten group function items. These were called Social Integration, Social Support, and Social Development. The first, Integration, was most closely associated with the social, familial, and cohesive nature of the group and included these three related items. Support had heaviest weightings on various emotional and material benefits (Hope, Belief Support, Catharsis, and Mutual Help). Finally, Social Development was associated primarily with items whose most apparent common link was to behavioral development and change (Information, Role Models, Interpersonal Learning, also Hope). In Table 1B each item is classified according to its heaviest loading on these factors. This assignment is clear except for two items. Catharsis has high loadings on both Integration and Support. Interpersonal Learning has high loadings on both Integration and Development. While this was somewhat problematic, assignment of these items to the subscales with which they had the highest loadings fortunately did not result in high inter-subscale correlations (see Table 2).

On the basis of the measured similarities of each group with each of the others, cluster analysis separated them into five distinct types. These results are summarized in Table 3 . Note that the clustering was done with subscales rather than factor scores because the former had better known psychometric properties.

\section{Self Interest Groups}

The first type was composed of nine liberation, minority, and civic groups organized to advocate a cause or promote the interests of a defined population. This included the National Organization of Women, Parents Without Partners, an anti-rape group as well as groups for American Indians, Japanese-Americans and parents of the retarded. Two politically oriented civic groups, Lions and Kiwanis and a similar group of sorority alumni, were also included. Structurally, they rated lower than average on Regulations and Boundary Control. Functionally, they rated low on Social Development. In comparison with other community group members, those of these groups had the shortest length of residence in the community.

These findings may have an interesting relation to the activities and composition of such groups. The high reliance on belief support is consistent with the political nature of most of these groups. They characteristically provide a forum for members to support mutual viewpoints, often in opposition to those common in the outside world. At the same time, however, the groups remain fairly casual with their lack of regulations. More speculatively, the freedom from regulations in these groups could be related to low levels of 
authoritarianism and tolerance of ambiguity found among members of some such groups (e.g., women's liberation groups ) (Pawlicki \& Almquist, 1973). It is also interesting to note while members were relatively new to the community, the group provided a link to the outer society by virtue of its low boundary control. Such groups could provide a foundation of social activity for a number of individuals new to the community and in need of social resources (see Table 3).

TABLE 3

Summary of the Group Profiles

\begin{tabular}{|c|c|c|c|c|}
\hline \multirow{2}{*}{$\begin{array}{c}\text { Type of } \\
\text { issessment }\end{array}$} & \multirow{2}{*}{ Variable } & \multicolumn{3}{|c|}{ Group Type } \\
\hline & & I Self-Interest & II. Self-llein & Iif 5oczal cominumion \\
\hline $\begin{array}{l}\text { Group } \\
\text { Structure } \\
\text { Scale }\end{array}$ & $\begin{array}{l}\text { Regulations } \\
\text { Role Demands } \\
\text { Boundary Control } \\
\text { S1ze }\end{array}$ & $\begin{array}{l}\text { Moderately Low* } \\
\text { Average } \\
\text { Moderately Low } \\
\text { Average }\end{array}$ & $\begin{array}{l}\text { High } \\
\text { Average } \\
\text { High } \\
\text { Average }\end{array}$ & $\begin{array}{l}\text { Moderately Low } \\
\text { Low } \\
\text { Average } \\
\text { High }\end{array}$ \\
\hline $\begin{array}{l}\text { Group } \\
\text { Function } \\
\text { Scale }\end{array}$ & $\begin{array}{l}\text { Social Irtegration } \\
\text { Social Support } \\
\text { Social Development }\end{array}$ & $\begin{array}{l}\text { Averáge } \\
\text { Average } \\
\text { Low }\end{array}$ & $\begin{array}{l}\text { High } \\
\text { High } \\
\text { High }\end{array}$ & $\begin{array}{l}\text { Moderately Hagh } \\
\text { High } \\
\text { Average }\end{array}$ \\
\hline $\begin{array}{l}\text { Demographic } \\
\text { Character- } \\
\text { 3stzcs of } \\
\text { Group } \\
\text { Members }\end{array}$ & $\begin{array}{l}\text { Mean Age } \\
\text { Female/Male Ratio } \\
\text { Percent Married } \\
\text { Mean Length of Membership } \\
\text { Mean Length of Residence } \\
\text { in County } \\
\text { Mean Number of Friends } \\
\text { Mean vumber of Group } \\
\text { Memberships } \\
\text { Mean Occupational Status } \\
\text { Percent Having a Work Group } \\
\text { Percent Living with Family }\end{array}$ & $\begin{array}{l}\text { Average } \\
\text { Average } \\
\text { Moderately Low } \\
\text { Moderately Low } \\
\text { Noderately Low } \\
\text { Average } \\
\text { Average } \\
\text { Average } \\
\text { Average } \\
\text { Average }\end{array}$ & $\begin{array}{l}\text { Moderately High } \\
\text { Average } \\
\text { Moderately Low } \\
\text { Average } \\
\text { Moderately High } \\
\text { Moderately Low } \\
\text { Moderately Low } \\
\text { Moderately Low } \\
\text { Average } \\
\text { Moderately High }\end{array}$ & $\begin{array}{l}\text { Average } \\
\text { Moderately High } \\
\text { High } \\
\text { Moderately High } \\
\text { Moderately High } \\
\text { Average } \\
\text { Average } \\
\text { Moderately Low } \\
\text { Moderately Low } \\
\text { Moderately Low }\end{array}$ \\
\hline $\begin{array}{l}\text { Suruary } \\
\text { Fermilla- } \\
\text { tzon }\end{array}$ & & $\begin{array}{l}\text { An informal foundation } \\
\text { of social contact for } \\
\text { individuals relatively } \\
\text { new to the community }\end{array}$ & $\begin{array}{l}\text { A social svstem re- } \\
\text { placenent to relieve } \\
\text { stress, restore sup- } \\
\text { port and facilitate } \\
\text { behavior change }\end{array}$ & $\begin{array}{l}\text { Large, casual } \\
\text { settings providing } \\
\text { family-ike sources } \\
\text { of support for indi- } \\
\text { viduals lacking } \\
\text { adequate sources } \\
\text { elsewhere }\end{array}$ \\
\hline
\end{tabular}

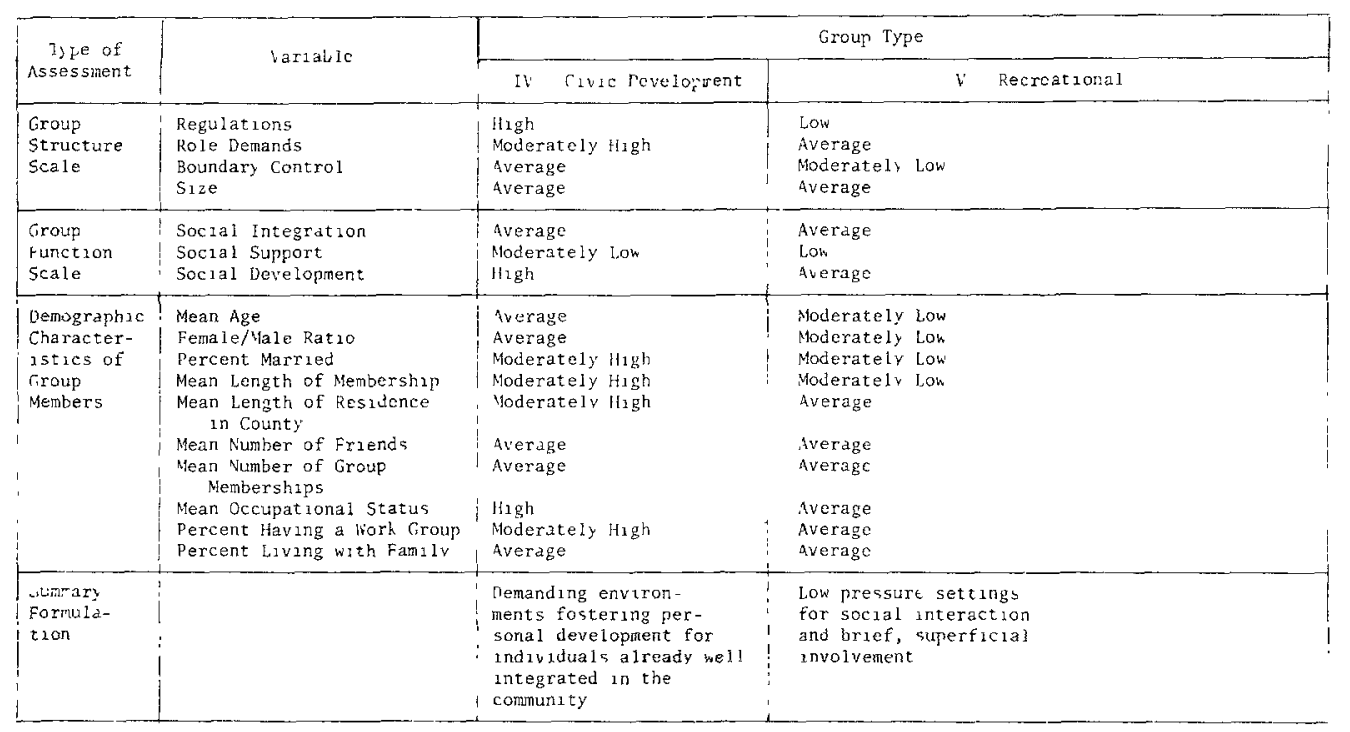

*Note. More precisely, the ratings on each vaxiabie mean that the standard score is greatex than 10 for "high", between +.3 and 1 for "Moderately" High", between -3 and .3 for "Average", between - 1.0 and " 3 for "Moderately Low", and $1 \mathrm{e} a \mathrm{~s}$ than -1.0 for "Low" 


\section{Self-Help Groups}

The second type was composed of several avowed SelfHelp groups, including ones for overeaters, neurotics, gamblers, smokers, and families of alcoholics. The activities of many of these groups are patterned after Alcoholics Anonymous, with readings, testimonials, and discussions. Reliance on a strict code of behavior and promoting conformity are often critical in the orientation of such groups toward individual behavior change (Crosbie, Petroni, \& Stitt, 1972). It is not too surprising then that they rated above average on most Regulations. Also consistent with this focus on behavior change, curative functions in these groups, including Support, Integration, and Development, were all high in comparison to the other groups.

On the other hand, Self-Help groups rated low on Role Demands and high on Boundary Control, possibly reflecting their ability to provide some isolation from external stress yet create few unnecessary internal demands. Entrance into the group was not restrictive and new members could remain completely silent if they wished.

Regarding membership characteristics, individuals in these groups tended to be older, of lower occupational status, and collectively at least, exhibited an unusual pattern of support. They were less often married, had fewer friends and group memberships, but more often lived with family. In view of this apparent reliance on family to the exclusion of other relations, especially when one considers the more anecdotal clinical reports that many self-help group members (e.g., alcoholics, drug addicts) complain of family distress, it is interesting to consider the possible role of such groups as social system replacements. Undoubtedly, their specific functions in promoting behavior change go beyond this. However, many such groups do actively encourage reliance on the group to the exclusion of outside contacts. For individuals who are typically socially deviant and who in general have few relations apart from kin, they also seem to provide alternative sources of support and social integration.

\section{Social Communion Groups}

The third type, composed of five women's prayer groups and social groups, mainly for the aged, offered a setting for social communion. These included clubs called the Optimists, the Night Owls, a retirees' club, and two Christian women's clubs. Although these groups had some organized activities and speakers, their main intent seemed to be providing a setting for people to congregate and interact in a supportive fashion. This often seemed to involve low interaction activity like praying, singing, and playing games rather than active socialization. Empirically, these groups were the largest of all those studied, but were relatively casual and undemanding, as evidenced by their below average ratings on Social Support, and provided some Social Integration. Participants had the longest member tenure and tended more often to be married and female. However, they less often lived with family, more seldom had a work group, and were below average in 
occupational status, indicating a deficiency in other sources of status and social relatedness.

Many of these qualities suggest an extended family-like character to these groups. They provide a casual setting (low Regulations and Role Demands) for support and social integration, are enduring (high member tenure) and may provide an abundance of social resources by virtue of their size. This is particularly interesting in view of the fact that members less often live with family and rate low on variables indicating other forms of support and status (work group, occupational status). Some authors have hypothesized that voluntary associations may serve to replace the loss of extended kinship ties in modern society-the social integration hypothesis (Sills, 1968). This is, of course, controversial. If this hypothesis indeed has validity for any of the groups studied, however, it would appear to have it for the Social Communion groups.

\section{Civic Development Groups}

The fourth type consisted of six groups, including four typical civic and service groups (named the Jaycees, Sertoma, Zonta, and The Grandmothers) and two clubs designed to teach specific skills (Toastmasters for public speaking and Parliamentarians for parliamentary procedure). Most provided experience in the planning and execution of community service projects.

As relatively formal and status-conscious settings, they were above average on Regulations and on some Role Demands (especially Selectivity). By contrast with other groups, predominant functions involved Social Development with a general deficiency of Social Support. Also sharply different from other group members, a higher percent of members of these groups had a work group and were married. They also had a higher mean length of residence in the community and had the highest occupational status.

The regulations, demands, developmental orientation, and relative lack of support in these groups provide a stark contrast to the atmosphere of the Social Communion group. Rather than providing supportive functions, these groups appear much more developmentally oriented, with the acquisition of leadership or other skills as a primary goal. For many individuals already well integrated in the community, it is possible then that such groups were as much a means to an end as an end in themselves.

\section{Recreational Groups}

The fifth and final cluster was composed of four avowed recreational clubs. This included a group of handicapped individuals organized to play games, a chess club, one for collecting coins, one for folk dancing, and one recreation-minded service group. Such groups were exceedingly activity oriented. Members often came solely to engage in some game (e.g., playing chess) and meetings often had little or no formal structure. 
Correspondingly, these groups were below average on all Regulations, and had a dearth of curative functions, especially of Social Support. In comparison with other groups, there was a higher percent of members who were young, male, unmarried, and with low membership tenure.

In general, such groups seemed to provide a casual, laissez-faire atmosphere (low Regulations) for brief involvement (low member tenure). One might speculate that these qualities would be preferred by persons who also lack great commitments elsewhere, like the young and unmarried, who collectively predominate in these groups.

\section{DISCUSSION}

In addition to addressing the theoretical need for identifying empirically discrete types of natural groupings, these data may have some practical value as a guide for the use of support groups in the community.

Suppose, for example, we were asked to recommend treatment for an elderly widow complaining of loneliness. Our interview reveals that she has adequate social skills but lacks an ongoing social network so we decide that community group referral may be an appropriate treatment adjunct. It appears also that her needs are related mainly to Social Support and Integration. Because of mild depression, however, she is strongly averse to pressures caused by group Regulations and Role Demands. We survey the community resources and find there are a number of groups of the Social Communion type that provide Support and Integration with few Regulations or Role Demands (see Table 3). Finding also that one of these is composed mainly of elderly widows, we refer her to this group to increase the likelihood she will find an environment in which she "fits," and begin to restore her network.

Similarly, the findings depicted in Table 3 could be used as a preliminary guide for other strategic referrals. People relying excessively on dysfunctional families and in need of Regulation in their lives might find an appropriate social system replacement in a Self-Help group. Unmarried young people unable to tolerate high group pressures might find an opportunity for brief undemanding involvement in a Recreational club. The findings might even be used for the design of preventive programs.

Suppose, for example, that a large minority group population has recently immigrated into the community. Many individuals have had difficulty adjusting, however, as evidenced by the high levels of mental illness and hospitalization among them. To attempt to change this we decide to provide a program offering community support groups. First, the fact that these individuals have risked the stress of immigration leads us to surmise that many would be hearty enough to tolerate considerable Role Demands in a group. At the same time, their dislike of formality suggests to us that they would be averse to excessive Regulations. To provide social roots for these individuals, therefore, we attempt to form a number of groups of the Self-Interest type with low Boundary Control and few Regulations. A step-by-step practical guide for 
these and other uses of community groups is provided in more detail in Politser and Pattison (in press).

These examples, of course, presuppose that we wish to help people find environments in which they "fit." This might not always be the case. We might, for instance, want to encourage personal development in a desired direction by referral to an organization that makes demands with which the client is not entirely comfortable (e.g., a Civic Development group). In other cases, professional judgment might dictate a choice of group entirely different from that suggested by our data. Certainly, many other factors besides one's fit with his group will be related to different kinds of therapeutic outcome. Also, while we have earlier documented that in some settings environmental fit appears related to positive outcomes, for many community group referrals the presence and extent of such relations are yet to be determined.

Likewise, it is important to note that the suggestions presented here are based (as is much data on treatment settings) on data pooled across different individuals. It is possible that seeking fit between the "average" individual and the "average characteristics" of a particular group type means something different from optimizing the fit of each individual with each group. A study using a common scale to assess the fit of particular individuals with particular groups would help clarify this issue.

This study should then be regarded as a beginning empirical base and set of concepts rather than a definitive set of guidelines. Much remains to be learned about the importance of various member and group characteristics in determining outcome. A definitive taxonomy also awaits a larger national sample. The historical mental health significance of community groups, the role of voluntary membership in promoting person-group fit, and the empirical relation of environmental fit to mental and physical health attributes all underscore the relevance of further research. While the actual value of such groups as referral sources or models is yet to be determined, their strategic use could represent a greatly needed addition to our therapeutic resources. The great popularity now enjoyed by Self-Help groups may be evidence of the need for such resources.

\section{REFERENCES}

Abramowitz, C. V. et al. Differential effectiveness of directive and non-directive group therapies as a function of chent internal-external control. Journal of Consulting and Clintcal Psychology, $1974,42,849-853$.

Anderson, R. T. Voluntary associations in history. American Anthropologist, 1971, 73, 209-222

Blau, Z. S. Old age in a changing soctety. New York: New Viewpoints, 1973.

Caplan, G. Support systems and community mental health. New York: Behavioral Publications, 1974.

Cobb, S. Social support as a moderation of life stress. Psychosomatic Medicine, 1976, 38, 300-314.

Crosbie, P. B., Petroni, P. O., and Stitt, B. G. The dynamics of "corrective" groups Journal of Health and Social Behavior, 1972, 13, 294-302.

Eddy, G. L., and Sinnet, R. Behavior setting utilization by emotionally disturbed college students. Journal of Consulting and Clinical Psychology, 1973, 40, 210-216.

Fredrickson, N. Toward a taxonomy of situations. American Psychologist, 1972, 27, 114-123.

French, J. R. P., Jr., and Caplan, R. D. Psychological factors in coronary heart disease. Industrial Medicine and Surgery, 1970, 39. 
Friedman, M. The passage through college. Soctal Issues, 1956, 12, 13-28.

Galanter, M. The "relief effect": A sociobiologic model for neurotic distress and large-group therapy. Presented at a panel, Social Science: New Perspectives for Psychiatry, 130th Annual American Psychiatric Association Convention, Toronto, Canada, May 5, 1977.

Kammeyer, I. C. W., and Botton, C. D. Community and family factors related to the use of a family service agency. Journal of Marriage, 1968, 30, 488-498.

Kerrı, J. N. Anthropological studies of voluntary associations and voluntary action: A review. Journal of Voluntary Action, 1972, 1, 43.

Levy, L. H. Self-help groups viewed by mental health professionals: A survey and comments. American Journal of Community Psychology, 1978, 6, 305-313.

Lieberman, M. Some limits to research on T groups. Journal of Applied Behavioral Science, 1975, II, 2.

Little, K. Voluntary associations and social mobility among West African women. Canadian Journal of African Studtes, 1972, 6, 275-288.

Lowenthal, M. E., and Haven, C. Interaction and adaptation: Intimacy as a critical variable. American Sociological Reveew, 1968, 33, 20-32.

Moos, R. Evaluating treatment environments: A social ecological approach. New York: Wiley, 1974.

Pace, C. R. The measurement of college environments. In R. Tagiurı and G. H. Litwin (Eds.), Organizational climate: Explorations of a concept. Boston: Graduate School of Business Administration, Harvard University, 1968.

Pace, C. R., and Stern, G. G. An approach to the measurement of psychological characteristics of college environments. Journal of Educational Psychology, 1958, 49, 269-277.

Paul, G. L. Chronic mental pattent: Current status-future directions. Psychological Bulletin, 1969, 71, 81-94.

Pawlicki, R. E., and Almquist, C. Authoritarianism, locus of control and tolerance of ambiguity as reflected in membership and nonmembership in a women's liberation group. Psychological Reports, 1973, 32, 1331-1337.

Pervin, L. A. Performance and satisfaction as a function of individual-environment fit. Psychological Bulletin, 1968, 69, 56-68.

Politser, P. E. Network Analysis and the Logic of Social Support. In R. H. Price and P. E. Politser (Eds.), Evaluation and action in the social environment, Academic Press, in press, 1980.

Politser, P. E., and Pattison, E. M. Communty groups. In R. H. Price and P. E. Politser (Eds.), Evaluation and action in the social environment, Academic Press, in press, 1980.

Price, R. H., and Moos, R H. Toward a taxonomy of inpatient treatment environments. Journal of Abnormal Psychology, 1975, 84, 181-188.

Reedy, R. D., and Smith, D. H. Who participates in voluntary action? Journal of Extension, 1973, $11,17$.

Sills, D. Voluntary associations: Sociological aspects. Internatonal Encyclopedia of the Social Sciences, 16, Macmillan and Free Press, Cambridge, 1968.

Singer et al. Boundary management. Journal of Applied Behavioral Science, 1975, II, 2.

Stunkard, A. J. The success of TOPS, a self-help group. Postgraduate medicine, 1972, 18, 143-147.

Trice, H. M., and Roman, P. M. Delabeling, relabeling, and Alcoholics Anonymous. Presented to the Section on Medical Sociology, Southern Sociological Society, New Orleans, Louisiana, 1969

Volkman, R., and Cressly, D. Differential association and the rehabilitation of drug addicts. American Journal of Sociology, 1963, 69, 129-142.

Wechsler, H., and Pugh, T. Fit of individual and community characteristics and rates of psychiatric hospitalization. American Journal of Soctology, 1967, 73, 331-338.

Yalom, I. D. Theory and practice of group psychotherapy. New York: Basic Books, 1970. 